\title{
Reversible Minimal Change Nephrotic Syndrome and Glomerular IgA Deposition Associated with Nonparenteral Heroin Abuse: A Case Report
}

\author{
Kenan Turgutalp ${ }^{a} \quad$ Ahmet Kiykim $^{a} \quad$ Umit Karabulut $^{\mathrm{a}} \quad$ Didar Gursoy $^{\mathrm{b}} \quad$ Iclal Gurses ${ }^{\mathrm{b}}$ \\ Departments of ${ }^{\mathrm{a}}$ Internal Medicine (Division of Nephrology) and ${ }^{\mathrm{b}}$ Pathology, School of Medicine, Mersin University, \\ Mersin, Turkey
}

Key Words

Glomerular disease · Nephrotoxicity · Proteinuria

\begin{abstract}
Objective: To report for the first time a case of reversible minimal change nephrotic syndrome with immunoglobulin A ( $\lg \mathrm{A})$ deposition associated with heroin. Clinical Presentation and Intervention: A 29-year-old male heroin abuser who developed nephrotic syndrome was admitted to our clinic. Renal biopsy revealed minimal change disease with IgA deposition. Because spontaneous complete remission was observed after cessation of heroin, a diagnosis of minimal change nephrotic syndrome with IgA deposition associated with heroin abuse was considered. Conclusion: This case showed minimal change nephrotic syndrome with IgA deposition that had a benign clinical course.
\end{abstract}

Copyright $\odot 2012$ S. Karger AG, Basel

\section{Introduction}

Diacetylmorphine, diamorphine (heroin), the most commonly abused drug [1], may result in several renal complications. A spectrum of glomerular abnormalities including focal segmental glomerulosclerosis, amyloidosis, focal glomerular sclerosis, minimal change disease, mesangial proliferation, and membranoproliferative glomerulonephritis have been reported in heroin users with renal disease [1]. Herein, we report a case of reversible minimal change nephrotic syndrome and immunoglobulin A (IgA) deposition in glomeruli associated with heroin.

\section{Case Report}

A 29-year-old man was referred to our clinic complaining of ankle and leg edema. History of gross hematuria, recent infection, gastrointestinal discomfort, arthralgia, use of systemic medication, and Henoch-Schönlein purpura were absent. He had been using heroin nonparenterally 3 times a week for 2 years. On physical examination, systolic blood pressure was $100 \mathrm{~mm} \mathrm{Hg}$ and diastolic blood pressure was $55 \mathrm{~mm} \mathrm{Hg}$. Other vital signs were normal. Symmetric ankle and leg edema was found. Organomegaly, lymphadenopathy, joint and skin abnormalities were not observed. Chest X-ray and echocardiography were normal. Abdominopelvic ultrasonography revealed increased kidney echogenicity. Renal Doppler ultrasonography was normal.

Laboratory findings on admission (table 1) were as follows: complete blood count: normal; serum creatinine: $0.8 \mathrm{mg} / \mathrm{dl}$ (normal ranges $0.5-0.9 \mathrm{mg} / \mathrm{dl}$ ); serum albumin: $2.8 \mathrm{~g} / \mathrm{dl}$; proteinuria: 3.9 g/day; LDL: $209 \mathrm{mg} / \mathrm{dl}$; erythrocyte sedimentation rate: $22 \mathrm{~mm} / \mathrm{h}$. Liver enzymes, fasting blood sugar, C-reactive protein and thyroid hormone levels were all normal. Urinalysis revealed microscopic hematuria (54 red blood cells/high power field), red blood cell cylinders and granular cylinders. Hepatitis B surface antigen, anti-HCV antibody, and HIV antibody were all negative. Complement 3 (C3) and 4, rheumatoid factor, antinuclear antibodies, anti-double-stranded DNA antibody and anti-neutrophil cytoplasmic antibodies were all negative. Serum IgA level was mildly elevated (436 mg/dl, normal range $80-350 \mathrm{mg} / \mathrm{dl}$ ). IgM, IgG and IgE levels were normal.

Renal biopsy was performed immediately. Light microscopy revealed mild mesangial expansion without endocapillary or ex-

\section{KARGER}

Fax +4161306 1234

E-Mail karger@karger.ch

www.karger.com
(C) 2012 S. Karger AG, Basel

$1011-7571 / 12 / 0215-0492 \$ 38.00 / 0$

Accessible online at:

www.karger.com/mpp
Dr. Kenan Turgutalp

Department of Internal Medicine, Division of Nephrology

School of Medicine, Mersin University

TR-33079 Mersin (Turkey)

Tel. +90 324337 4300, E-Mail k.turgutalp@ hotmail.com 


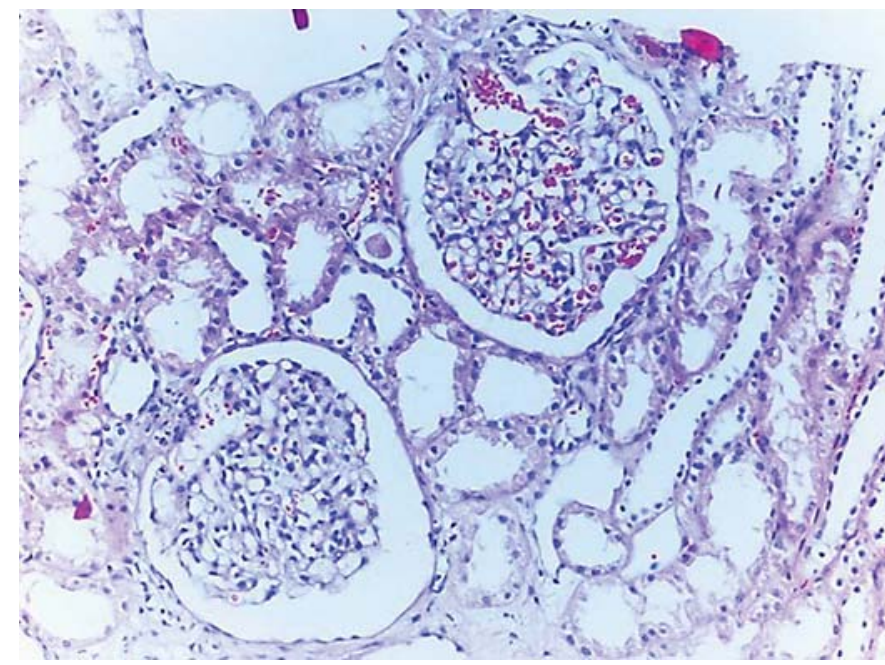

Fig. 1. Immunofluorescence microscopy: anti-IgA intense staining within the mesangium of glomeruli. $\times 400$.

tracapillary proliferation in all glomeruli, and congestion in capillary loops. Segmental or global sclerosis of glomeruli was not observed. Tubulointerstitial area was normal. Congo red staining for amyloidosis was negative. Intense (4+) IgA-C3 deposits, and milder (1+) IgG and fibrinogen deposits in all glomeruli were seen in immunofluorescence microscopy (fig. 1). Isolated subendothelial deposits and foot process effacement were detected by electron microscopy (fig. 2). Amyloid fibrils were absent.

Because of histopathological findings, the diagnosis of IgA nephropathy or minimal change nephrotic syndrome with IgA deposition was considered. The patient discontinued the use of heroin. An angiotensin-converting enzyme inhibitor, ramipril, was started, but was discontinued due to symptomatic hypotension 3 days later. The patient was treated with dietary recommendations. Proteinuria decreased gradually without immunosuppressive treatment. Consequently complete clinical and laboratory remission were observed after 4 months of the cessation of heroin. Proteinuria and serum albumin levels returned to normal levels. Urinalysis revealed no microscopic hematuria and cylinders. A second renal biopsy was recommended to the patient for re-evaluation of histopathological changes, especially IgA deposition, but the patient refused rebiopsy. However, the patient did not give a specific reason for his refusal. His blood pressure was 115/75 $\mathrm{mm} \mathrm{Hg}$, serum creatinine was $0.6 \mathrm{mg} / \mathrm{dl}$, proteinuria was $75 \mathrm{mg} / \mathrm{day}$, serum IgA level was $421 \mathrm{mg} / \mathrm{dl}$, and there were no red blood cells and cylinders in urine after 6 months of remission (table 1).

\section{Discussion}

In this report, we demonstrated minimal change nephrotic syndrome associated with intense IgA deposition in a heroin abuser.

Reversible Nephrotic Syndrome Associated with Heroin Abuse

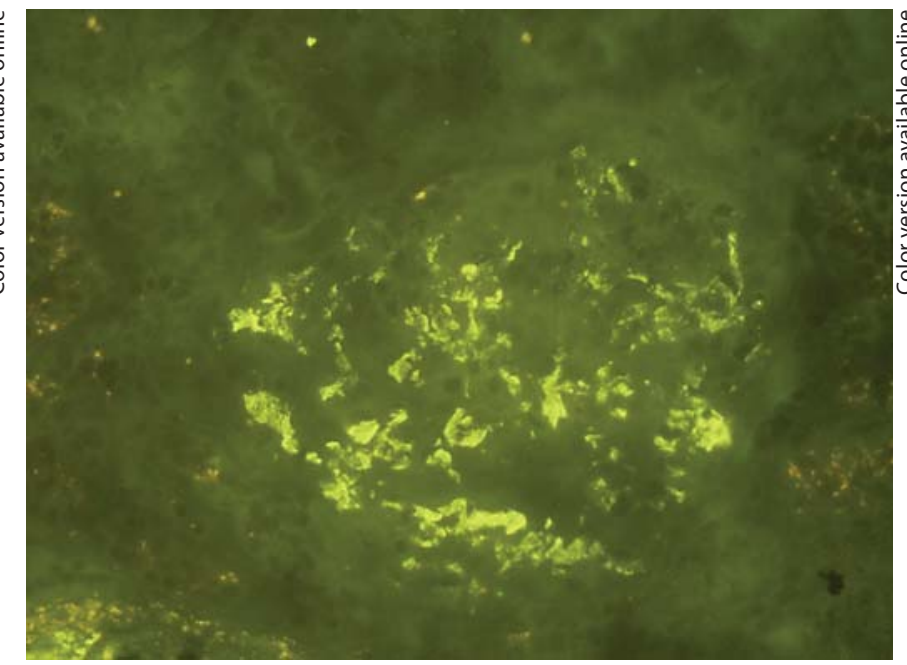

Fig. 2. Electron microscopy: subendothelial granular deposits, effacement of pedicles. Amyloid fibrils were not found. $\times 12,000$.

Table 1. Laboratory findings on admission and follow-up

\begin{tabular}{lllll}
\hline \multirow{2}{*}{ Parameters } & \multirow{2}{*}{$\begin{array}{l}\text { On } \\
\text { admis- } \\
\text { sion }\end{array}$} & $\begin{array}{l}\text { Outpatient follow-up without } \\
\text { heroin }\end{array}$ \\
\cline { 3 - 5 } & & 1 month & 4 months & 6 months \\
\hline Hemoglobin, g/dl & 14.1 & 14.3 & 14.5 & 15.0 \\
WBC/ $\mu$ l & 7,900 & 6,500 & 7,200 & 5,800 \\
Platelets, $\times 10^{3} / \mu \mathrm{l}$ & 210 & 305 & 270 & 205 \\
Serum creatinine, mg/dl & 0.8 & & 0.7 & 0.6 \\
eGFR, ml/min & 102 & & 104 & 114 \\
Serum albumin, g/dl & 2.8 & 3.0 & 4.1 & 4.4 \\
Proteinuria, mg/24h & 3,900 & 1,400 & 110 & 75 \\
RBC in urine/hpf & 54 & 8 & 0 & 0 \\
CRP, mg/l & 1.4 & 1 & 0.5 & 0.6 \\
TSH, $\mu$ IU/ml & 0.74 & & & 0.85 \\
C3, g/l & 1.21 & & & 1.40 \\
C4, g/l & 0.32 & & & 0.26 \\
HBsAg & $(-)$ & & & $(-)$ \\
HCV antibody & $(-)$ & & & $(-)$ \\
HIV antibody & $(-)$ & & & $(-)$ \\
IgA, mg/dl & 436 & & & 421 \\
IgG, g/l & 7.9 & & & 8.0 \\
IgE, IU/ml & 24 & & & 31 \\
IgM, g/l & 0.7 & & & 1.0 \\
\hline
\end{tabular}

eGFR $=$ Estimated glomerular filtration rate by MDRD equation; $\mathrm{WBC}=$ white blood cell count $\mathrm{RBC}=$ red blood cell count; $\mathrm{CRP}=\mathrm{C}$-reactive protein; $\mathrm{TSH}=$ thyroid-stimulating hormone; hpf = high power field; HBsAg = hepatitis B surface antigen.

Med Princ Pract 2012;21:492-494 
Heroin can be sniffed, eaten, smoked, or injected parenterally. There is a high rate of contamination of infectious agents including HIV, hepatitis C, and hepatitis B associated with parenteral heroin abuse. Glomerulonephritis may be associated with these infections [2]. On the other hand, secondary amyloidosis has increased in frequency as a cause of nephropathy in drug abusers, particularly among those who inject drugs subcutaneously [3]. However, our patient did not use heroin parenterally and there was no evidence of HIV, hepatitis C, or hepatitis B infection.

Minimal change disease (MCD) is a disease of unknown cause. The secondary forms of MCD can be the result of drugs (nonsteroidal anti-inflammatory drugs), neoplastic disease (Hodgkin's disease), infections, and allergic reactions (similar to an insect sting). MCD is increasingly recognized as a complication of therapy with a variety of agents. In many cases, a hypersensitivity reaction rather than a direct toxic effect appears to be involve [4]. In our case, there were no skin rashes or fever, and by light microscopy there was no finding of tubulointerstitial nephritis. Thus, the hypersensitive reaction might not be a pathogenetic mechanism for underlying proteinuria in the patient. However, Morgenstern et al. [5] indicated that drugs could cause MCD without accompanying tubulointerstitial inflammation, as in our patient.

Mesangial deposition of IgA can be found in many diseases and some patients without overt kidney disease, of which IgA nephropathy is the prototype. Because of the presence of foot process effacement, absence of alterations of glomerular basal membrane, absence of glomerular sclerosis, and achieving complete clinical remission after cessation of heroin, IgA nephropathy was not considered. Since rebiopsy was refused by the patient, there is no data about glomerular IgA deposition after complete remission. In general in MCD, there are neither immunoglobulins nor complement fraction deposition in renal tissue. In exceptional cases, there are deposits of $\operatorname{IgM}, \operatorname{IgG}, \operatorname{Ig} A$ or $\mathrm{C} 3$ in mesangium. Intense mesangial IgA deposition has rarely been reported in MCD [6]. The clinical importance of mesangial deposits of IgA remains unclear although Westhoff et al. [7] identified IgA deposition as a risk factor for impairment of renal function and indicated a frequently relapsing course, whereas Choi et al. [6] did not.

Heroin abuse has been associated with alterations in cellular and humoral immune function in humans. Blanck et al. [8] reported significant elevations of IgM and IgG above normal range in intravenous heroin users, and significant elevations of $\operatorname{IgA}$ above controls were found in nonparenteral heroin users as in our patient. The higher IgA in nonparenteral heroin users was presumed to reflect local antibody synthesis [8]. IgA deposition has also been demonstrated in the damaged alveolar capillary membrane of 6 heroin addicts [9]. The pathogenesis of these IgA-associated abnormalities and the clinical significance remain unclear.

The treatment approach of glomerular disease associated with heroin use remains unclear. While our patient achieved complete clinical remission as previously reported [10], Tan et al. [11] reported treatment with colchicine to decrease proteinuria.

\section{Conclusion}

This case showed minimal change nephrotic syndrome with IgA deposition that had a benign clinical course.

\section{References}

1 Jaffe JA, Kimmel PL: Chronic nephropathies of cocaine and heroin abuse: a critical review. Clin J Am Soc Nephrol 2006;1:655-667.

-2 do Sameiro Faria M, Sampaio S, Faria V, Carvalho E: Nephropathy associated with heroin abuse in Caucasian patients. Nephrol Dial Transplant 2003;18:2308-2313.

3 Crowe AV, Howse M, Bell GM, Henry JA: Substance abuse and the kidney. QJM 2000; 93:147-152.

-4 Hong YH, Yun DY, Jung YW, Oh MJ, Kim HJ, Lee CK: A case of minimal change disease treated successfully with mycophenolate mofetil in a patient with systemic lupus erythematosus. Korean J Intern Med 2011; 26:470-473.
5 Morgenstern SJ, Bruns FJ, Fraley DS, Kirsch M, Borochovitz D: Ibuprofen associated lipoid nephrosis without interstitial nephritis. Am J Kidney Dis 1989;14:50-52.

6 Choi J, Jeong HJ, Lee HY, Kim PK, Lee JS, Han DS: Significance of mesangial IgA deposition in minimal change nephrotic syndrome: a study of 60 cases. Yonsei Med J 1990;31:258-263.

7 Westhoff TH, Waldherr R, Loddenkemper C, Ries W, Zidek W, van der Giet M: Mesangial IgA deposition in minimal change nephrotic syndrome: coincidence of different entities or variant of minimal change disease? Clin Nephrol 2006;65:203-207.
8 Blanck RR, Ream N, Deegan MJ: Immunoglobulins in heroin users. Am J Epidemiol 1980;111:81-86.

9 Smith WR, Glauser FL, Dearden LC, Wells ID, Novey HS, McRae DM, Newcomb KA: Deposits of immunoglobulin and complement in the pulmonary tissue of patients with 'heroin lung'. Chest 1978;73:471-476.

10 Llach F, Descoeudres C, Massry SG: Heroin associated nephropathy: clinical and histological studies in 19 patients. Clin Nephrol 1979;11:7-12.

11 Tan AU Jr, Cohen AH, Levine BS: Renal amyloidosis in a drug abuser. J Am Soc Nephrol 1995;5:1653-1658. 